\title{
The permanent struggle for hope: Three suburban pieces Tony Ullyatt ${ }^{1}$
}

\section{The home sweet home paranoia syndrome [Variations on two themes by David Cooper]}

From the womb we are born into the box of the family from which we progress into the box of the school. $B y$ the time we leave school we have become so conditioned to being in a box that from then on we erect our own box, prison, bin around us - until, finally with relief, we are put into the coffin or the oven.

David Cooper

There is no hope. There is only permanent struggle. That is our hope.

David Cooper

back then, in the 60 s, most folks lived in 'boxes, little boxes, made of ticky-tacky' they even crooned about those home sweet homes

in clichéd pretty sing-song ditties nowadays, the ticky-tacky is more sumptuous

each box fitted out with all mod cons barricades of Devil's fork screaming alarms and blinding lights

all unlikely to bring anyone running from their homes for fear they might get killed or

worse still

maimed in some wanton mêlée

the ageing canary that hung in a cage from a skew verandah beam

chirped his last Carpe Diem long ago

a steel-barred cage prevents the thieves from being led into temptation and absconding with our cars at night guns lie zealously under the bed poised for the instant

the dogs of war begin to snap and snarl

we do our Sunday oblations armoured in the certainty God will deliver us from evil but just in case

we beseech the help of Devil's fork to keep the demons out our churches and to keep the demons in our mental asylums and old-age homes while graveyards nestle in the keen embrace of razor-wire and fences even the dead must feel secure although we're on our own in the suburbs we'll never be lonely 
wedded as we are to the terror and its shadow they settle in

colonising our minds

making themselves at home like family

unpacking their paranoiac baggage

meanwhile

incarcerated in our fragile tin-roofed forts

we do battle with our daily dread

unlikely unwilling or unable

to forgive those who trespass against us

the ineffable questions sired in the shadow of death

still torment us

paranoia / parə' пэю/ noun.

[Origin: Modern Latin from Greek, from paranoos distracted, formed as para ${ }^{1}+$ noos, nous $=$ mind

1. Orig., dementia. Now, a mental illness characterized by

delusions of persecutions, unwarranted jealousy, or exaggerated self-importance.

2. A tendency to suspect and distrust others or to believe oneself unfairly used.

syndrome /0'sindrerm/ noun.

[Origin: Modern Latin from Greek sundromē, from sun- syn- + drom-, dramein run.]

A group of symptoms or pathological signs which consistently occur together; a condition characterized by such a set of associated symptoms.

Shorter Oxford English dictionary

\section{Suffer, little children \\ [Variations on a theme of Mary Lamb]}

A child's a plaything for an hour*

Mary Lamb

her father

robust city councillor, stout pillar of the church

taught her the tricks of pleasuring him

when she was five or six

he always waited until her mother had gone to work

too small to clamber over the Devil's fork

she was too small for revenge

she loathed the sight of him

especially afterwards

and on Sundays in church

resting his paternal hand high up on her thigh nothing sacred there

like a spectator at an execution her mother smiled her Sunday smile

dear jesus the child would pray i could come to heaven now and be with you safe for ever and ever

but jesus must have been busy with more important things

when at last her father had a heart attack -

the notion of a defenceless assault pleased her -

she listened to the crematorium's fiery furnace

then threw his ashes on the wind-swept rubbish dump - another wicked irony -

but still

the tendrils of her wretchedness coil relentlessly about her

*This quotation comes from Lamb's book entitled, ironically, Parental recollections. 


\section{'To love, honour, and obey' [Variations on a theme of William Shakespeare]}

Such duty as the subject owes his prince

Even such a woman oweth her husband*

William Shakespeare

for years she felt the weekdays go by

with every blow every clout every punch every pummel every hit

every smack every strike every bash

every flat of the hand every fist

MONday-TUESday-WEDnesDAY-THURSday-FRIday

then

the weekends came around as unstoppable

as his pulverising barrage

her face swollen eyes shut lips split

jaw broken ribs cracked

so she could scarcely breathe

some teeth gone too

then he'd weep and blamed the drink

he couldn't give up

if the truth be known he wouldn't give up

he'd tried so many times and failed over and over

he beat her for that

then he'd weep

she said she would leave

he beat her for that then he'd weep

she said she would call the police

he beat her for that then he'd weep

she said she would take the kids

he beat her for that

then he'd weep

she took refuge with friends

he beat her for that

then he'd weep

she even said she loved him

he beat her for lying

then he'd weep and weep

making promises she knew he could never keep

in fact would never keep

or even make an effort to

he was still snivelling and grovelling and pleading

when she blew his brains out

using the revolver he'd threatened her with

umpteen times before

his family said she was the worst thing that ever happened to this good man he was kind and gentle and loving and a wonderful father

but

his brutish language

attached completely different meanings

to the terrible words

she discovered in his dictionary by mistake

kindness

gentleness

forgiveness

love

* The taming of the shrew V.ii.156 